\title{
Ebola, fragile health systems and tuberculosis care: a call for pre- emptive action and operational research
}

\author{
R. Zachariah,* N. Ortuno, ${ }^{\dagger}$ V. Hermans, ${ }^{*}$ W. Desalegn,§ S. Rust,* A. J. Reid,* M. J. Boeree," \\ A. D. Harries $\# * *$
}

\begin{abstract}
*Operational Research Unit, Brussels Operational Centre, Médecins Sans Frontières (MSF), Luxembourg; ${ }^{\dagger}$ Damien Foundation, Conakry, Guinea; ${ }^{\ddagger}$ MSF, Bo Town, Sierra Leone; ${ }^{\S}$ Akilu Lemma Institute of Pathobiology, Addis Ababa University, Addis Ababa, Ethiopia; "Department of Pulmonary Diseases, Radboudumc Nijmegen/Universitair Centrum voor Chronische Ziekten Dekkerswald, Nijmegen University, Nijmegen, The Netherlands; \#International Union Against Tuberculosis and Lung Disease, Paris, France; **London School of Hygiene \& Tropical Medicine, London, UK
\end{abstract}

S U M M A R Y

The Ebola outbreak that started in late 2013 is by far the largest and most sustained in history. It occurred in a part of the world where pre-existing health systems were already fragile, and these deteriorated further during the epidemic due to a large number of health worker deaths; temporary or permanent closure of health facilities; nonpayment of health workers; intrinsic fear of contracting or being stigmatised by Ebola among the population, which negatively influenced health-seeking behaviour; enforced quarantine of Ebola-affected communities, restricting the access of vulnerable individuals to health facilities; and late response by the international community. There are also reports of drug and consumable stockouts due to deficiencies in the procurement and supply chain as a result of overriding Ebola-related priorities. Providing tuberculosis (TB) care and achieving favourable treatment outcomes require a fully functioning health system, accurate patient tracking and high patient adherence to treatment. Furthermore, as Ebola is easily transmitted through body fluids, the use of needles-essential for TB diagnosis and treatment-needs to be avoided during an outbreak. We highlight ways in which a sustained Ebola outbreak could jeopardise TB activities and suggest pre-emptive preventive measures while awaiting operational research evidence.

KEY WORDS: operational research; needles; TB treatment; HIV testing; Ebola outbreak
After climbing a great hill, one only finds that there are many more hills to climb.

\section{Nelson Mandela}

THESE WORDS WILL RESONATE with anyone involved with providing health care in Ebola-affected countries in West Africa. Although the recent decline in reported Ebola cases brings some relief, there are still many hills to climb. The Ebola epidemic that started in late 2013 is the largest and most sustained in the history of Ebola outbreaks, ${ }^{1-3}$ occurring in a part of the world with already fragile infrastructures, characterised by disparities in the availability of health care resources, infrastructural deficiencies ${ }^{4}$ and lack of access to care. ${ }^{1}$ The epidemic has exacerbated this situation for several reasons.

First, the three most affected countries in West Africa have some of the highest rates of patients per physician in the world: over 100000 patients per physician in Liberia, ${ }^{5} 50000$ in Sierra Leone ${ }^{5}$ and 10000 in Guinea, ${ }^{6}$ compared to 312 patients per physician in France and 400 in the United States. ${ }^{6}$ The
pre-Ebola staff shortage was made even worse by the 512 Ebola-related deaths among health workers to date, while an estimated $21 \%$ of the overall health work force in Sierra Leone, $15 \%$ in Liberia and 1.5\% in Guinea has actually disappeared.7,8

Second, several health facilities closed down temporarily or permanently due to fear among health workers of contracting Ebola. ${ }^{9}$ This fear was compounded by a lack of adequate training about Ebola disinfection, a paucity of personal protective equipment (PPE) and non-payment of risk-related incentives, leading to strikes and refusal of health workers to return to work. ${ }^{10,11}$

Third, staff from programmes such as the Expanded Programme on Immunisation (EPI), malaria control, human immunodeficiency virus/acquired immune-deficiency syndrome (HIV/AIDS) and tuberculosis (TB) (Figure) were repurposed to activities related to Ebola control, leading to a progressive deterioration in and even collapse of some of the routine health care services. ${ }^{12}$

Correspondence to: Rony Zachariah, Médecins Sans Frontières, Brussels Operational Centre, 68 Rue de Gasperich, Luxembourg. Tel: (+352) 661332 516. Fax: (+352) 335 133. e-mail: rony.zachariah@brussels.msf.org

Article submitted 29 April 2015. Final version accepted 17 August 2015. 


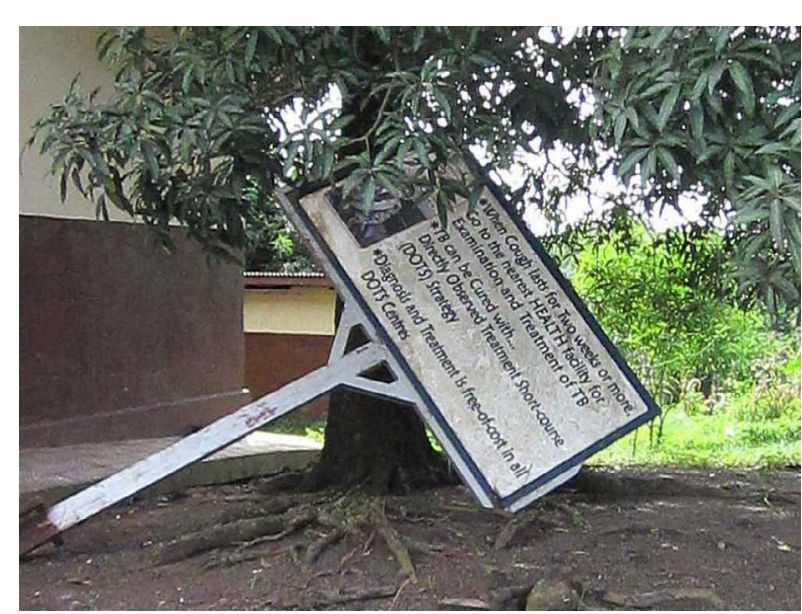

Figure An uprooted tuberculosis-related signpost beside a clinic where staff were repurposed in an Ebola-affected country in West Africa. This image can be viewed online in colour at http://www.ingentaconnect.com/content/iuatld/ijtld/2015/ 00000019/000000011/art00003

Finally, fear among the population and the enforced quarantine of Ebola-affected communities created stigma and negatively influenced healthseeking behaviour, restricting the access of vulnerable individuals to health facilities and care. ${ }^{2,13}$

The negative effects of the sustained Ebola epidemic on health services have been demonstrated in several areas. In Sierra Leone, there were considerable declines in hospital in-patient admissions and numbers of patients undergoing major surgery. ${ }^{14}$ In Liberia, $60 \%$ of the 144 HIV/AIDS clinics in the country were shut down, severely affecting HIV/AIDS care. ${ }^{12,15}$ Loss to follow-up among individuals on ART in the Donka National Hospital in Conakry, Guinea, escalated from $0 \%$ to $42 \% .{ }^{16}$ In Guinea, attendance at maternal health services has considerably declined; ${ }^{17}$ the situation is similar for malaria consultations ${ }^{18}$ and routine EPI vaccinations. ${ }^{19}$

Although no reports on the effect of the current Ebola outbreak on TB control efforts have been published as yet, it makes intuitive and logical sense that the outbreak did impact TB care. Operational research is needed to document the real effects of Ebola on TB control, and we call on TB stakeholders to investigate and report on this issue in the affected countries.

It is well known that $\mathrm{TB}$ management requires a fully functioning health system, including trained health workers, a well-functioning laboratory network, a robust supply chain for drugs and consumables, accurate and regular tracking of patients and their outcomes, and high patient adherence to treatment. ${ }^{20}$ Furthermore, as Ebola is easily transmitted through body fluids, the use of needlesessential for HIV diagnosis in TB patients and treatment of retreatment $\mathrm{TB}$ cases-needs to be avoided during an Ebola outbreak. ${ }^{21}$
Ebola can affect TB management in various ways. TB diagnostic centres may not function at normal capacity, resulting in a decline in the numbers of presumptive TB patients being screened and diagnosed with TB. Recent data showing a considerable drop in diagnosed and notified malaria cases in Guinea support the belief that the same situation may have happened in the case of TB. ${ }^{18} \mathrm{HIV}$ testing among TB patients, which relies on the finger-prick test (not recommended during an Ebola outbreak), may decrease, leading to a reduction in the number of individuals diagnosed with HIV. Shortcomings in ascertaining HIV status will affect the uptake of both cotrimoxazole preventive therapy-needed for preventing opportunistic diseases-and antiretroviral treatment (ART). Individuals diagnosed with TB and referred to the health facilities to initiate antituberculosis treatment may have been unable to receive treatment due to health facility closures or other overriding Ebola-related priorities that reduced patient access to care. This situation would negatively influence survival and foster TB transmission in the community. Furthermore, as anti-tuberculosis treatment in the most Ebola-affected countries is based on supervised pill swallowing and/or administration of injectables at health facilities under direct observation by health workers, those already on treatment may face difficulties in receiving their medications. This situation may increase adverse TB outcomes such as death, loss to follow-up and treatment failure, as well as increased risk of drug resistance. Finally, there are anecdotal reports of drug and consumable stockouts as routine drug procurement and supply activities are overwhelmed by Ebola-related supply priorities.

These specific issues need urgent operational research to assess the impact of Ebola on health systems that provide $\mathrm{TB}$ care, so that when the number of Ebola cases rise again we have practical solutions on how to improve TB management. Although the World Health Organization (WHO) 2015 global TB report will publish data on TB case notifications, HIV testing, cotrimoxazole and ART uptake as well as treatment outcomes, these data will only become available toward the latter half of 2015, and may be difficult to interpret due to weaknesses in data collection during the epidemic. Meanwhile, as the Ebola outbreak has continued well into 2015, adopting a 'wait and see' approach would be a mistake. Action to sustain TB programmes must be pre-emptive, and existing knowledge can already be put to good use. The Table highlights various ways in which we can act now while awaiting evidence from operational research.

Some important messages have already emerged. First, the Ebola epidemic has highlighted the interdependence of all disease control programmes, including $\mathrm{TB}$ control, in a robust health system infrastructure. 
Table Various ways in which a sustained Ebola outbreak could hinder TB-related activities, and possible ways forward

\begin{tabular}{|c|c|c|c|}
\hline Activity & Ebola outbreak-related events & Possible implications & Ways forward \\
\hline \multicolumn{4}{|c|}{ TB diagnosis and resistance testing } \\
\hline $\begin{array}{l}\text { Screening for presumptive } \\
\text { TB } \\
\text { TB culture and } \\
\text { susceptibility testing }\end{array}$ & $\begin{array}{l}\text { Health facility closures due to } \\
\text { health worker deaths and } \\
\text { fear } \\
\text { Repurposing of TB staff to Ebola } \\
\text { control activities } \\
\text { Stigma against and fear of } \\
\text { health facility visits among } \\
\text { the population and health } \\
\text { workers }\end{array}$ & $\begin{array}{l}\text { Reduced numbers of } \\
\text { presumptive TB patients } \\
\text { screened and diagnosed } \\
\text { resulting in more 'missed } \\
\text { cases' } \\
\text { Reduced numbers of } \\
\text { retreatment TB and MDR-TB } \\
\text { diagnosed }\end{array}$ & $\begin{array}{l}\text { Re-establish trust by ensuring } \\
\text { health worker and facility } \\
\text { safety } \\
\text { Enhance community awareness } \\
\text { Need for easy-to-use, point-of- } \\
\text { care screening tests for TB } \\
\text { that reduces workload* }\end{array}$ \\
\hline \multicolumn{4}{|l|}{ HIV diagnosis } \\
\hline $\begin{array}{l}\text { HIV testing among TB } \\
\text { patients }\end{array}$ & $\begin{array}{l}\text { Current HIV testing relies on } \\
\text { drawing blood using the } \\
\text { finger prick test, which } \\
\text { should be avoided during an } \\
\text { Ebola outbreak }\end{array}$ & $\begin{array}{l}\text { Decline in HIV testing and } \\
\text { reduced uptake of key HIV } \\
\text { related interventions, such as } \\
\text { cotrimoxazole prophylaxis } \\
\text { and antiretroviral treatment }\end{array}$ & $\begin{array}{l}\text { Use oral (swab-based) HIV } \\
\text { testing (e.g., Oraquick) in } \\
\text { Ebola-endemic areas }\end{array}$ \\
\hline \multicolumn{4}{|l|}{ Anti-tuberculosis treatment } \\
\hline $\begin{array}{l}\text { Administration of anti- } \\
\text { tuberculosis treatment }\end{array}$ & $\begin{array}{l}\text { Possible delays in initiating anti- } \\
\text { tuberculosis treatment } \\
\text { among diagnosed TB patients } \\
\text { due to health facility closures, } \\
\text { reduced access or staff } \\
\text { shortage } \\
\text { Fear of visiting health facilities } \\
\text { hinders health facility-based } \\
\text { administration of TB pills and } \\
\text { injectables } \\
\text { Possible interruption of anti- } \\
\text { tuberculosis treatment by TB } \\
\text { patients on similar grounds }\end{array}$ & $\begin{array}{l}\text { Increase in missed TB cases, } \\
\text { increased community TB } \\
\text { transmission and related } \\
\text { deaths. } \\
\text { Compromised adherence will } \\
\text { contribute to the } \\
\text { development of drug } \\
\text { resistance and unfavourable } \\
\text { treatment outcomes }\end{array}$ & $\begin{array}{l}\text { Request additional national and } \\
\text { international staff support to } \\
\text { ensure that health facilities } \\
\text { continue to function } \\
\text { Resort to guardian- or } \\
\text { community-based drug } \\
\text { administration (task shifting) } \\
\text { to reduce health facility } \\
\text { dependence and workload }\end{array}$ \\
\hline $\begin{array}{l}\text { Management of } \\
\text { retreatment TB }\end{array}$ & $\begin{array}{l}\text { Daily injections of streptomycin } \\
\text { (mainstay of the drug } \\
\text { regimen for this TB category) } \\
\text { may be dropped by health } \\
\text { workers or patients } \\
\text { themselves due to fear of } \\
\text { contracting Ebola }\end{array}$ & $\begin{array}{l}\text { The compromised drug regimen } \\
\text { may contribute to the } \\
\text { development of drug } \\
\text { resistance and unfavourable } \\
\text { treatment outcomes }^{\neq}\end{array}$ & $\begin{array}{l}\text { Introduce a triage system to } \\
\text { identify TB patients with } \\
\text { possible Ebola. Ensure } \\
\text { universal precautions and } \\
\text { strict infection control } \\
\text { Consider a new retreatment } \\
\text { regimen without injections }\end{array}$ \\
\hline Treatment of MDR-TB & $\begin{array}{l}\text { Use of second-line injectable } \\
\text { drugs may be dropped by } \\
\text { health workers }\end{array}$ & $\begin{array}{l}\text { Compromised MDR-TB } \\
\text { regimens will contribute to } \\
\text { the development of drug } \\
\text { resistance and unfavourable } \\
\text { outcomes }\end{array}$ & $\begin{array}{l}\text { Triage system and universal } \\
\text { precautions as for } \\
\text { retreatment TB } \\
\text { Consider MDR-TB regimens } \\
\text { without injectables }\end{array}$ \\
\hline \multicolumn{4}{|l|}{ Procurement and supply } \\
\hline Dugs and consumables & $\begin{array}{l}\text { Stockouts may occur due to } \\
\text { over-riding Ebola-related } \\
\text { priorities }\end{array}$ & $\begin{array}{l}\text { Interruption of routine TB- and } \\
\text { HIV-related activities. }\end{array}$ & $\begin{array}{l}\text { Provide health facilities and } \\
\text { patients with buffer stocks (a } \\
\text { 'safety net') } \\
\text { Consider task shifting of drug } \\
\text { distribution to expert patients }\end{array}$ \\
\hline
\end{tabular}

* Available only for MDR-TB

${ }^{+}$Undiagnosed TB patients in the community and diagnosed patients who do not start anti-tuberculosis treatment.

${ }^{\text {* } T r e a t m e n t ~ o u t c o m e s ~ i n c l u d e ~ t r e a t m e n t ~ s u c c e s s, ~ d e a t h, ~ l o s s ~ t o ~ f o l l o w-u p, ~ f a i l u r e, ~ t r a n s f e r ~ o u t ~ a n d ~ d e a t h . ~ U n f a v o u r a b l e ~ o u t c o m e s ~ i n c l u d e ~ d e a t h, ~ l o s s ~ t o ~ f o l l o w-u p ~}$ and failure.

$\mathrm{TB}=$ tuberculosis; MDR-TB = multidrug-resistant TB; HIV = human immunodeficiency virus.

This requires adequate numbers of accessible health facilities, sufficient quantities of trained health staff, health facility safety (ensuring safety of both staff and patients), adequate logistics, a functioning health information and surveillance system, ongoing procurement and supply chain management and good governance. All of these need adequate funding, and there has been a call to set up a dedicated International Health Systems Fund at the WHO. ${ }^{22}$ This fund would help improve emergency response capabilities in the event of epidemics by boosting health system devel- opment in the most affected countries. ${ }^{22} \mathrm{~TB}$ and HIV programmes will need such support to counter future Ebola epidemics.

Second, the current culture of neglecting infection prevention and control and the safety of health facilities needs to change. ${ }^{10,23,24}$ All health workers must be adequately trained in infection control, provided with the necessary PPE and practise universal health precautions. While international and national staff in Ebola treatment centres were presented through the media in spacesuit-like protec- 
tive gear, the reality for most ordinary health workers in peripheral health facilities was that they had to work without even the basic PPE. ${ }^{10,15}$ Such a dichotomy is not acceptable. ${ }^{7}$

Keeping health facilities safe would reduce fear and re-establish trust among health workers to continue providing essential health care services in times of Ebola outbreaks, reduce nosocomial health worker infections and deaths, ${ }^{23}$ prevent perceptions in the population that health facilities are unsafe places to seek care and strengthen the much needed interaction between disease-specific programmes and health systems. ${ }^{24}$ Keeping health facilities safe is of huge relevance to TB control as well. ${ }^{24}$

Third, access to health care for the health workforce in Ebola-affected regions was minimal. While international health staff infected with Ebola were rapidly evacuated abroad and offered the highest standards of care, national staff at the beginning of the epidemic had very limited access to specialised care. Even those who worked in the Ebola treatment centres had poor access, let alone those working in other disease control programmes such as TB. Ensuring universal access to specialised health facilities for all health workers affected by epidemic diseases such as Ebola ${ }^{25}$ in the region should be a priority. Such facilities should have the capacity for rapid action even when the current epidemic is over. Prioritised access to vaccines, such as the inclusion of health care workers in the STRIVE (Sierra Leone Trial to Introduce a Vaccine against Ebola) Ebola virus disease vaccine study by the US Centers for Disease Control and Prevention, as is being conducted in Sierra Leone, should be encouraged. The interim results from the rVSV-vectored vaccine (a vaccine vectored by recombinant vesicular stomatitis virus) trial showed $100 \%$ protective efficacy against Ebola in Guinea, which is encouraging; this vaccine should be made available to health workers on a priority basis. ${ }^{26}$ It goes without saying that new Ebola treatments for health workers should be made available free of charge. ${ }^{23}$

The issue of occupational health for health workers needs more focused attention. What is needed is to establish a dedicated WHO umbrella unit that guides health worker and facility safety, i.e., occupational health. The WHO could then support the creation of similar units within the Ministries of Health, which would be accountable for monitoring and addressing infection control issues across programmes. Their activities should involve dedicated safety planning, implementation and continued supervision and monitoring-activities that cannot simply be annexed to any individual disease control programme. The Ebola epidemic showed that lax health worker safety affected countries far beyond the epicentres of the disease. A dedicated investment in occupational health in resource-poor countries is in the best interests of global public health.

Like many disease control programmes that have come up with ambitious global plans, the WHO has launched the Post 2015 End TB Strategy-an implementation plan to end the global TB epidemic. ${ }^{27}$ Although this is laudable, such plans can only work if the broader health system environment in which they are implemented is safe for both health workers and patients.

In conclusion, we call for urgent operational research to document the effects of Ebola on TB control and suggest some strategies that can be introduced already to better sustain TB care during future epidemics.

\section{Acknowledgements}

This paper was conceived and written up at an African Structured Operational Research and Training Initiative (SORT IT) course. SORT IT is a global partnership led by the Special Programme for Research and Training in Tropical Diseases at the World Health Organization (WHO/TDR), Geneva, Switzerland.

Conflicts of interest: none declared.

\section{References}

1 Gostin L O, Lucey D, Phelan A. The Ebola epidemic: a global health emergency. JAMA 2014; 312: 1095-1096.

2 Piot P, Muyembe J J, Edmunds W J. Ebola in west Africa: from disease outbreak to humanitarian crisis. Lancet Infect Dis 2014; 14: 1034-1035.

3 World Health Organization. Ebola virus disease in West Africa-the first 9 months of the epidemic and forward projections. N Engl J Med 2014; 371: 1481-1495.

4 Fauci A S. Ebola-underscoring the global disparities in health care resources. N Engl J Med 2014; 371: 1084-1086.

5 World Health Organization. WHO country profiles. Geneva, Switzerland. WHO, 2015. http://www.who.int/countries/en/ Accessed August 2015.

6 World Bank. Open data: physicians (per 1000 people). Washington DC, USA: World Bank, 2015. http://data. worldbank.org/indicator/SH.MED.PHYS.ZS Accessed August 2015.

7 World Health Organization. Ebola response roadmap: situation report. WHO/EVD/Roadmap/14.1Geneva, Switzerland: WHO, 2014. http://apps.who.int/iris/bitstream/10665/ 131596/1/EbolaResponseRoadmap.pdf Accessed August 2015.

8 World Health Organization. Global Health Observatory. Density of nursing and midwifery personnel, per 1000 population. Geneva, Switzerland: WHO, 2015. http://www. who.int/gho/health_workforce/nursing_midwifery_density/en/

9 Ulrich C M. Ebola is causing moral distress among African healthcare workers. BMJ 2014; 349: g6672.

10 Delamou A, Beavogui A H, Konde M K, van Griensven J, De Brouwere V. Ebola: better protection needed for Guinean health care workers. Lancet 2015; 385: 503-504.

11 Honigsbaum M. Ebola: epidemic echoes and the chronicle of a tragedy foretold. Lancet 2014; 384: 1740-1741.

12 Edelstein M, Angelides P, Heymann D L. Ebola: the challenging road to recovery. Lancet 2015; 385: 2234-2235.

13 Philips M, Markham A. Ebola: a failure of international collective action. Lancet 2014; 384: 1181.

14 Bolkan H A, Bash-Taqi D A, Samai M, Gerdin M, von Schreeb J. Ebola and indirect effects on health service function in Sierra Leone. PLoS Curr 2014; 6: pii. 
15 Tattevin P, Baysah M K, Raguin G. Retention in care for HIVinfected patients in the eye of the Ebola storm. AIDS 2015; 29: N1-2.

16 Ndawinz J D, Cissé M, Diallo M S, Sidibé C T, D’Ortenzio E. Prevention of HIV spread during the Ebola outbreak in Guinea. Lancet 2015; 385: 1393.

17 Delamou A, Hammonds R M, Caluwaerts S, Utz B, Delvaux T. Ebola in Africa: beyond epidemics, reproductive health in crisis. Lancet 2014; 384: 2105.

18 Plucinski M M, Guilavogui T, Sidikiba S, et al. Effect of the Ebola-virus-disease epidemic on malaria case management in Guinea, 2014: a cross-sectional survey of health facilities. Lancet Infect Dis 2015 Jun 23. [Epub ahead of print]

19 Takahashi S, Metcalf C J, Ferrari M J, et al. Reduced vaccination and the risk of measles and other childhood infections post-Ebola. Science 2015; 34: 1240-1242.

20 Kieny M P, Evans D B, Schmets G, Kadandale S. Health-system resilience: reflections on the Ebola crisis in western Africa. Bull World Health Organ 2014; 92: 850.

21 Beeching N J, Fenech M, Houlihan C F. Ebola virus disease. BMJ 2014; 349: g7348.
22 Gostin L O. Ebola: towards an International Health Systems Fund. Lancet 2014; 384: e49-51.

23 Dallatomasina S, Crestani R, Sylvester Squire J, et al. Ebola outbreak in rural West Africa: epidemiology, clinical features and outcomes. Trop Med Int Health 2015; 20: 448-454.

24 Harries A D, Zachariah R, Tayler-Smith K, et al. Keeping health facilities safe: one way of strengthening the interaction between disease-specific programmes and health systems. Trop Med Int Health 2010; 15: 1407-1412.

25 Dahmane A, van Griensven J, Van Herp M, et al. Constraints in the diagnosis and treatment of Lassa Fever and the effect on mortality in hospitalized children and women with obstetric conditions in a rural district hospital in Sierra Leone. Trans $\mathrm{R}$ Soc Trop Med Hyg 2014; 108: 126-132.

26 Henao-Restrepo A M, Longini I M, Egger M D, et al. Efficacy and effectiveness of an rVSV-vectored vaccine expressing Ebola surface glycoprotein: interim results from the Guinea ring vaccination cluster-randomised trial. Lancet 2015; 1016: 1-9.

27 World Health Organization. The End TB Strategy. Geneva, Switzerland: WHO, 2015. http://www.who.int/tb/post2015 strategy/en/. Accessed August 2015. 
L'épidémie d'Ebola qui a débuté fin 2013 est de loin la plus importante et la plus durable de l'histoire. Elle est survenue dans une partie du monde où les systèmes de santé préexistants étaient déjà fragiles et ont continué à se détériorer pendant l'épidémie pour les raisons suivantes : nombre considérable de décès dans le personnel de santé ; fermeture temporaire ou permanente des structures de santé ; pas de paiement des salaires du personnel de santé ; peur de contracter la maladie ou d'être stigmatisé par Ebola dans la population, ce qui a eu une influence négative sur la demande de soins ; mise en œuvre de la quarantaine dans les communautés affectées par Ebola, ce qui a restreint l'accès des plus vulnérables aux structures de santé ; et réponse tardive de la communauté internationale. On a également rapporté des ruptures de stock de médicaments et de consommables dues aux défaillances de la chaine de commande et d'approvisionnement, résultant de la priorité absolue accordée à Ebola. Soigner la tuberculose $(\mathrm{TB})$ et obtenir un bon résultat du traitement requiert un système de santé parfaitement fonctionnel, un suivi précis des patients et une bonne adhésion des patients au traitement. De plus, comme Ebola est facilement transmis par les liquides biologiques, l'utilisation d'aiguilles - essentielle au diagnostic et au traitement de la TB - doit être évitée pendant une épidémie. Nous soulignons les manières dont une épidémie prolongée d'Ebola pourrait mettre en danger les activités liées à la TB et nous suggérons des mesures de prévention en attendant des preuves émanant d'une recherche opérationnelle.

\section{RES U M E N}

El brote epidémico de enfermedad por el virus del Ébola que comenzó a finales del 2013 es, con mucho, el más extenso y el más sostenido de la historia. Este brote ocurrió en una zona del mundo donde los sistemas de salud prexistentes eran ya frágiles y se deterioraron aun más durante la epidemia, debido a los siguientes factores: la defunción de un número considerable de trabajadores de salud; el cierre transitorio o permanente de establecimientos sanitarios; la falta de pago a los trabajadores de salud; el temor íntimo de contraer el virus o ser estigmatizado por la enfermedad en la población, lo cual influyó de manera negativa sobre los comportamientos de búsqueda de atención de salud; la cuarentena obligatoria de las comunidades afectadas por la enfermedad del Ébola; la restricción del acceso de las personas vulnerables a los establecimientos sanitarios; $y$ la respuesta tardía de la comunidad internacional. Asimismo, existen informes sobre desabastecimientos de medicamentos y materiales fungibles por deficiencias en la adquisición y la cadena de suministro, como resultado de las prioridades absolutas vinculadas a la enfermedad del Ébola. La atención de la tuberculosis (TB) y el logro de desenlaces terapéuticos favorables exigen un sistema de salud plenamente operativo, precisión en la localización de los pacientes y gran cumplimiento terapéutico por parte de los pacientes. Además, dada la alta transmisibilidad del virus del Ébola por los líquidos y las secreciones corporales, durante un brote epidémico es necesario evitar el uso de agujas y este es fundamental en el diagnóstico y el tratamiento de la TB. En el presente artículo se destacan los mecanismos por los cuales un brote sostenido de enfermedad del Ébola podría poner en peligro las actividades contra la TB y se proponen medidas preventivas anticipatorias en espera de datos fidedignos de las investigaciones operativas. 